\title{
Implementasi Pembiayaan Akad Murabahah dalam Upaya Peningkatan UMKM di KSPPS Permata Barokah Jaya Kelurahan Pandaan
}

\author{
Siti Ayu Rochmaniah ${ }^{1 *}$, Renny Oktafia ${ }^{2)}$ \\ Fakultas Agama Islam, Universitas Muhammadiyah Sidoarjo \\ *Email korespondensi: niaayu074@gmail.com
}

\begin{abstract}
Abstrak
Usaha Mikro, Kecil dan Menengah (UMKM) merupakan sekumpulan orang yang berprofesi sebagai pelaku usaha, yang memiliki keinginan untuk meningkatkan pendapatan pribadi dan juga masyarakat luas. Namun hal tersebut tentunya memerlukan dukungan khusus dari Lembaga Keuangan Mikro Syariah sendiri, salah satunya yakni Koperasi Syariah. Penelitian ini bertujuan untuk mengetahui bagaimana Implementasi pembiayaan Akad Murabahah serta upaya peningkatan Usaha Mikro, Kecil dan Menengah (UMKM) di KSPPS Permata Barokah Jaya Kelurahan Pandaan. Peneliti memilih menggunakan metode penelitian kualitatif dengan pendekatan studi kasus. Hasil penelitian ini menunjukkan bahwa Implementasi Akad Murabahah yang diminati oleh banyak anggota pembiayaan pada KSPPS Permata Barokah Jaya, telah sesuai dengan prinsip Syariah. Namun untuk upaya peningkatan Usaha Mikro, Kecil dan Menengah (UMKM) pada KSPPS Permata Barokah Jaya masih belum dapat maksimal memberikan pembiayaan bagi pelaku usahanya, dikarenakan pembiayaan Akad Murabahah pada KSPPS Permata Barokah Jaya didominasi oleh anggota yang berprofesi sebagai karyawan Pabrik. Karyawan Pabrik ini, dianggap dapat lebih memudahan pihak KSPPS Permata Barokah Jaya dalam mensurvey calon anggota, serta penyertaan jaminan berupa ATM Gaji anggota.
\end{abstract}

Kata kunci: akad murabahah, KSPPS, peningkatan UMKM

\section{Abstract}

Micro, Small and Medium Enterprises (MSMEs) are a group of people who work as business actors, who have a desire to increase personal income and also the wider community. However, this certainly requires special support from the Islamic Microfinance Institution itself, one of which is the Sharia Cooperative. This study aims to determine how the implementation of Murabahah Akad financing and efforts to increase Micro, Small and Medium Enterprises (MSMEs) at KSPPS Permata Barokah Jaya, Pandaan Village. Researchers chose to use qualitative research methods with a case study approach. The results of this study indicate that the implementation of the Murabahah Agreement which is in demand by many financing members at KSPPS Permata Barokah Jaya is in accordance with the principles of Sharia. However, efforts to increase Micro, Small and Medium Enterprises (UMKM) at KSPPS Permata Barokah Jaya are still not able to provide maximum financing for business actors, because the Murabahah Akad financing at KSPPS Permata Barokah Jaya is dominated by members who work as factory employees. This factory employee, is considered to be able to make it easier for the KSPPS Permata Barokah Jaya in surveying prospective members, as well as the inclusion of guarantees in the form of a member Salary ATM.

Keywords: murabahah agreement, KSPPS, UMKM improvement

Saran sitasi: Rochmaniah, S. A., \& Oktafia, R. (2021). Implementasi Pembiayaan Akad Murabahah dalam Upaya Peningkatan UMKM di KSPPS Permata Barokah Jaya Kelurahan Pandaan. Jurnal Ilmiah Ekonomi Islam, 7(02), 1038-1047. doi: http://dx.doi.org/10.29040/jiei.v7i2.2531

DOI: http://dx.doi.org/10.29040/jiei.v7i2.2531

\section{PENDAHULUAN}

Negara Indonesia memiliki banyak penduduk yang mayoritas menganut Agama Islam. Agama Islam sendiri merupakan Agama Dakwah yang bertugas untuk memperkenalkan dan menyiarkan ajaran Syari'at Islam kepada penjuru Dunia. Pengetahuan terkait pemahaman mengenai pentingnya menjalankan Syari'at Islam inilah yang kemudian 
pertama kali menjadi pemicu berdiri dan berkembangnya Lembaga Keuangan Bank maupun Lembaga Keuangan Non Bank yang berbasis dengan sistem Syariah. Perkembangan Lembaga Keuangan non Bank saat ini banyak tumbuh di tengah-tengah masyarakat Indonesia, baik yang berdiri diatas naungan pemerintah maupun yang didirikan langsung oleh Masyarakat. Lembaga Keuangan non Bank berupaya untuk meningkatkan pemberdayaan masyarakat, khususnya bagi yang memiliki penghasilan menengah ke bawah dan masyarakat yang berpartisipasi dalam bidang usaha mikro, kecil dan menengah (UMKM) (Otoritas Jasa Keuangan, 2017). Tentunya hal tersebut memerlukan dukungan secara inklusif dari Lembaga Keuangan itu sendiri. Kendala terkait pendanaan atau pembiayaan dapat diatasi dengan adanya Lembaga Keuangan yang berfokus terkait hal tersebut. Lembaga Keuangan yang dimaksud yakni dikenal dengan Lembaga Keuangan Mikro (LKM). Bentuk badan hukum LKM yakni Perseroan Terbatas (PT) dan Koperasi, baik dengan sistem Konvensional maupun Sistem Syariah (Haryanto, 2011).

Entitas Koperasi Syariah saat ini tengah mengalami perkembangan yang cukup signifikan. Rincian data menunjukkan bahwa jumlah Koperasi Syariah kurang lebih sekitar 123.048 unit, dengan jumlah total aset sekitar Rp. 152.113.137,04,- Juta Rupiah yang berasal dari 34 Provinsi di Indonesia. Provinsi Jawa Timur menjadi salah satu provinsi yang memiliki jumlah Koperasi Syariah terbanyak dengan menempati posisi pertama yang berjumlah kurang lebih sekitar 21.757 unit, dengan jumlah total aset sekitar kurang lebih Rp. 26.215.314,66,- Juta Rupiah yang tersebar pada tiap Kecamatan dan Kabupaten di Jawa Timur (Kementerian Koperasi Dan Usaha Mikro Kecil Dan Menengah, 2019). Koperasi Simpan Pinjam menjadi Koperasi yang paling banyak mendominasi unit perkoperasian di Indonesia, juga merupakan Koperasi yang paling banyak dijalankan dari sejak tahun 2000. Koperasi Simpan Pinjam ini dianggap dapat menguntungkan dan juga dapat membantu masalah anggotanya terkait hal keuangan. Koperasi Simpan Pinjam ini melakukan kegiatan penghimpunan dana dari anggotanya, yang kemudian disalurkan kembali kepada anggota atau masyarakat umum serta pelaku Usaha Mikro Kecil dan Menengah (UMKM) yang membutuhkan bantuan dana (Badan Pusat Statistik Indonesia, 2019).
Banyaknya pelaku Usaha Mikro, Kecil dan Menengah (UMKM), peran dari Koperasi Syariah terkait Lembaga Keuangan yang memberikan pinjaman atau pembiayaan harus lebih ditingkatkan dan dikembangkan, serta dikelola agar bersifat lebih efisien (Nuryanto, dkk., 2014); (Budiantoro et al., 2018). Hal yang paling penting dan harus senantiasa ditingkatkan dalam pelaksanaan UMKM yakni sistem Syariah Islam. Selain mendapatkan rezeki dari usaha yang ditekuni, pelaku usaha juga akan mendapatkan keberkahan dalam setiap pekerjaannya (Oktafia, 2017). Jumlah UMKM di Indonesia mengalami peningkatan dari tahun sebelumya. Berdasarkan rincian data UMKM telah mencapai angka 64.194.057 unit di Tahun 2018. Sedangkan pada Tahun sebelumnya 2017, UMKM Berjumlah kurang lebih 62.922.617 Unit. Peningkatan yang terjadi selama tahun 2017 hingga 2018 mencapai 1.271.440 unit (Kementerian Koperasi Dan Usaha Mikro Kecil Dan Menengah, 2018). Dengan jumlah yang semakin meningkat inilah peran Koperasi Simpan pinjam dan pembiayaan syariah sangat diperlukan untuk membantu pelaku UMKM dalam mengembangkan usaha yang dimilikinya (Budiantoro et al., 2018).

Berbasis dengan sistem Syariah, Koperasi Simpan Pinjam dan Pembiayaan Syariah (KSPPS) adalah koperasi yang kegiatan usahanya meliputi simpanan, pinjaman dan pembiayaan yang sesuai dengan prinsip syariah. Didalam Koperasi Simpan Pinjam dan Pembiayaan Syariah, diterapkan berbagai sistem Pembiayaan seperti, Akad Mudharabah, Akad Musyarakah, Akad Murabahah dan lain sebaganya. Menjadi salah satu Akad yang paling banyak diminati, Akad Murabahah memiliki sistem penerapan yang sederhana dan tingkat resiko kerugian yang minim (Ilyas \& Sartika, 2018); (Tho'in \& Prastiwi, 2019).

Koperasi Simpan Pinjam dan Pembiayaan Syariah (KSPPS) berada di tengah-tengah masyarakat untuk membantu membangun perekonomian yang berwawasan Syariah (Sari \& Rusdiono, 2020). Salah satu dari banyaknya Koperasi Simpan Pinjam dan Pembiayaan Syariah (KSPPS) yang menerapkan pembiayaan Akad Murabahah ialah KSPPS Permata Barokah Jaya kelurahan Pandaan. Akad Murabahah (Bai' al-murabahah) berasal dari bahasa arab, yakni ribhu yang berarti keuntungan. Murabahah merupakan akad pembiayaan jual beli dengan memberitahukan harga asli barang dan menambahkan sejumlah keuntungan yang telah disepakati pada awal perjanjian antara pihak Koperasi Simpan Pinjam dan 
Pembiayaan Syariah (KSPPS) dan Nasabah harus saling menyetujui terkait harga dan juga jangka waktu pembayaran sebelum akad berhasil disahkan (Bonita \& Anwar, 2018).

Kegiatan Jual beli dalam Islam, merupakan suatu kegiatan yang sangat dianjurkan penerapannya. Selain untuk mencari keuntungan duniawi, jual beli juga untuk mencari keridhoan Allah SWT (Hakim \& Anwar, 2017). Hal tersebut sudah dijelaskan dalam Firman Allah SWT yakni tertera pada Al-Qur'an Surah An-Nisa: 29 sebagai berikut:

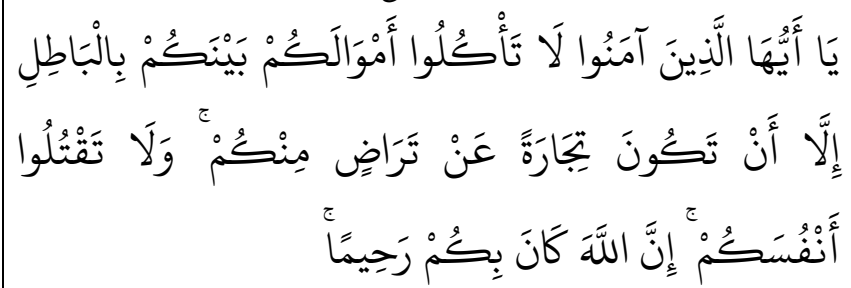

Artinya: Hai orang-orang yang beriman, janganlah kamu saling memakan harta sesamamu dengan jalan yang batil, kecuali dengan jalan perniagaan yang berlaku dengan suka sama-suka di antara kamu. Dan janganlah kamu membunuh dirimu; sesungguhnya Allah adalah Maha Penyayang kepadamu.

Dalam Al Hadist juga dijelaskan bahwa Islam memperbolehkan penerapan Akad Murabahah (Jual beli), hal tersebut tertera dalam Hadits riwayat AlBaihaqi dan Ibnu Majah, dinilai shahih oleh Ibnu Hibban, bahwa Nabi Muhammad SAW bersabda:

Artinya: Dari Abu Sa'id Al-Khudri bahwa Rasulullah SAW bersabda, "Sesungguhnya jual beli itu harus dilakukan suka sama suka." (HR. alBaihaqi dan Ibnu Majah, dan dinilai shahih oleh Ibnu Hibban).

Akad Murabahah dapat dilakukan dengan dua cara yaitu Murabahah tanpa pemesanan dan Murabahah dengan pemesanan. Murabahah tanpa pemesanan, dilakukan dengan cara pengadaan objek yang sudah ada sebelumnya, tanpa melihat ketersediaan stok objek ada atau tidak. Sedangkan Murabahah dengan pemesanan yakni harus memesan dan menanyakan ketersediaan barang terlebih dahulu, apabila tidak ada pemesanan, maka pengadaaan barang tidak dilakukan oleh pihak penjual. Agar tidak terjadinya penimbunan barang yang tidak perlu (Hakim \& Anwar, 2017). Pembayaran Akad Murabahah dibedakan menjadi dua yaitu, pembayaran yang dilakukan secara tunai, dengan langsung memberikan uang tunai saat setelah barang diterima. Dan pembayaran yang dilakukan secara tangguh, dengan tidak langsung melakukan pembayaran pada saat itu juga, melainkan secara tangguh atau angsuran sesuai dengan batas waktu yang telah disepakati sebelumnya oleh pihak KSPPS dan anggota pembiayaan, atau pembayaran kontan di akhir sesuai dengan kesepakatan (Novita et al., 2014).

Jual beli dengan sistem tangguh atau angsuran diperbolehkan, bukan termasuk golongan Riba. Adapun dalil yang memperbolehkan pembelian secara tangguh diriwayatkan oleh Bukhari dan Muslim, "Dari Aisyah R.A. yang menjelaskan bahwa Rasulullah SAW pernah membeli makanan dari seorang yahudi secara tangguh dengan menggadaikan baju besi miliknya" (HR. Bukhari dan Muslim) (Imama \& Shoa, 2014).

Usaha Mikro, Kecil dan Menengah (UMKM) memiliki definisi yang diatur dalam suatu UndangUndang Republik Indonesia Nomor 20 Tahun 2008 tentang UMKM. Dalam Undang-Undang tersebut tertera bahwa Usaha Mikro ialah usaha produktif milik orang atau perseorangan atau badan usaha yang telah memenuhi kriteria Usaha Mikro. Usaha Kecil merupakan usaha ekonomi produktif yang berdiri sendiri, dilakukan oleh orang atau perseorangan atau badan usaha yang bukan berasal dari bagian anak perusahaan, bukan pula cabang yang dimiiliki, dikuasai, atau menjadi bagian baik secara langsung maupun secara tidak langsung dari Usaha Kecil tersebut. Usaha Menengah ialah usaha ekonomi produktif, yang berdiri sendiri, dilakukan oleh orang atau perseorangan atau badan usaha yang memiliki jumlah kekayaan bersih sebagamana dimaksud dalam Undang-Undang.

UMKM memliki beberapa peran penting untuk dapat memeratakan pendapatan dan membantu pertumbuhan ekonomi melalui penyediaan lapangan kerja yang cukup, untuk masyarakat yang membutuhkan pekerjaan (Anggraeni et al., 2013). Diperlukan kesadaran akan pentingnya berwirausaha, yang dapat direalisasikan melalui kebijakan dalam program permodalan, target subsidi untuk usahausaha kecil serta melahirkaan usaha-usaha baru. UMKM akan lebih terbantu dengan adanya Lembaga Keuangan Mikro Syariah, seperti Koperasi Simpan Pinjam dan Pembiayaan Syariah (KSPPS) yang akan membantu masalah terkait hal keuangan, seperti permodalan, pelengkap usaha dan lain sebagainya (Novita et al., 2014). 
Permasalahan yang paling sering terjadi pada KSPPS Permata Barokah Jaya ialah permintaan pembiayaan yang diajukan oleh Nasabah dipergunakan untuk pembelian barang pribadi seperti Sepeda Motor, Handphone dan lain sebagainya, bukan dipergunakan untuk pelengkap suatu usaha atau modal usaha. Masalah selanjutnya, terkait fokus pemberian pembiayaan oleh KSPPS Permata Barokah Jaya, permintaan dari pelaku usaha baru atau pelaku usaha lama menjadi hal yang paling sering ditolak pengajuannya, sedangkan permintaan yang paling diutamakan ialah berasal dari Karyawan tetap Perusahaan, dikarenakan gaji yang dimiliki oleh Karyawan tetap bersifat sama setiap bulannya.

\section{METODE PENELITIAN Jenis Penelitian}

Jenis metode penelitian yang digunakan oleh peneliti yakni Metode penelitian kualitatif dengan menggunakan pendekatan studi kasus. Peneliti memilih menggunakan metode studi kasus dikarenakan penelitian dilakukan secara langsung oleh pihak informan yang bersangkutan seperti Manajemen KSPPS Permata Barokah Jaya, Staf pembiayaan KSPPS Permata Barokah Jaya, dan anggota pembiayaan yang bersangkutan (Sugiyono, 2017).

\section{Lokasi penelitian}

Penelitian akan dilakukan oleh peneliti di Kelurahan Pandaan Kabupaten Pasuruan, tepatnya pada KSPPS Permata Barokah Jaya. Alasan melakukan penelitian hanya pada satu tempat saja dikarenakan peneliti ingin mendapatkan hasil yang maksimal dan memperoleh data yang diperlukan terkait dengan Implementasi akad Murabahah pada KSPPS Permata Barokah Jaya dalam peningkatan UMKM.

\section{Jenis Data dan Sumber Data}

Peneliti menggunakan dua jenis data yakni data primer, peneliti akan mengambil data yang diperoleh dari wawancara kepada Manajer KSPPS Permata Barokah Jaya, Staf pembiayaan KSPPS Permata Barokah Jaya, dan anggota pembiayaan yang bersangkutan. Sedangkan Data sekunder yakni diperoleh Peneliti dari Website resmi Otoritas Jasa Keuangan, Badan Pusat Statistik Indonesia, Badan Pusat statistik Kabupaten Pasuruan, Kementerian Koperasi dan Usaha Kecil Menengah (Hasiara, 2012).

Teknik Pengumpulan Data
Teknik dalam pengumpulan data Terdapat tiga macam, yaitu Observasi yakni peneliti akan mengamati berbagai aktivitas yang dilakukan oleh pihak informan pada lokasi penelitian dengan menggunakan teknik partisipasi pasif, yang mana peneliti hanya akan mengamati tanpa melibatkan diri dalam kegiatan yang dilakukan oleh informan. Dengan begitu, peneliti hanya akan bertindak sebagai Observer atau pengamat. Wawancara yakni peneliti akan menanyakan terkait berbagai informasi yang diperlukan. Teknik wawancara seperti ini disebut dengan wawancara terstruktur. Dalam hal ini, peneliti mendatangi lokasi informan yang bertempat di KSPPS Permata Barokah Jaya pada waktu jam kerja. Dikarenakan peneliti ingin mengamati berbagai kegiatan di lokasi. Selanjutnya, dikarenakan pada saat diluar dari jam kerja, pihak informan sibuk dan tidak dapat memberikan informasi terkait penelitian. Teknik pengumpulan data yang ketiga yakni, Dokumentasi merupakan suatu pelengkap dari Observasi dan Wawancara yang berisikan berbagai bukti foto, rekaman suara, dan lain-lain yang menjadi sumber informasi terkait Akad Murabahah pada KSPPS Permata Barokah Jaya (Raco, J, 2010).

\section{Teknik Analisis dan Interpretasi Data}

Peneliti memilih menggunakan model Miles \& Huberman dalam Teknik analisis dan Interpretasi data yakni yang pertama Reduksi data, menyederhanakan dan merangkum data yang terlalu banyak, serta memilih data yang diperlukan oleh peneliti, sehingga data tersebut dapat memberikan suatu gambaran atas apa yang tengah diteliti. Penyajian data dalam penelitian bersifat naratif, yang bersumber dari hasil wawancara peneliti dengan Manajer KSPPS Permata Barokah Jaya, Staf pembiayaan KSPPS Permata Barokah Jaya, dan anggota pembiayaan. Data yang didapat dari pihak informan yakni data yang dapat menjawab dua rumusan masalah. Penyajian data ialah data informasi yang terstruktur dan didapatkan dari hasil observasi selama penelitian dilaksanakan. Penarikan kesimpulan, berisi deskripsi data dari hasil penelitian yang digunakan untuk menjawab rumusan masalah terkait Implementasi Akad Murabahah pada Koperasi Simpan Pinjam dan Pembiayaan Syariah (KSPPS) di desa Pandaan dalam upaya peningkatan usaha mikro (Sugiyono, 2017).

\section{Uji Kredibilitas}

Triangulasi penelitian terdapat tiga teknik yakni Pertama Triangulasi Sumber, yaitu data yang didapatkan dari sumber yang berbeda, Manajer 
KSPPS Permata Barokah Jaya, Staf pembiayaan KSPPS Permata Barokah Jaya dan anggota pembiayaan. Sumber yang didapatkan menghasilkan pernyataan yang sama, jika dalam KSPPS Permata Barokah Jaya menggunakan Akad Murabahah.

Triangulasi teknik, data diperoleh dari Manajer KSPPS Permata Barokah Jaya, Staf pembiayaan KSPPS Permata Barokah Jaya, dan anggota pembiayaan dengan menggunaan teknik wawancara terkait dengan Akad murabahah pada KSPPS Permata Barokah Jaya, kemudian diuji kembali pada saat observasi, untuk mendapatkan data yang sama dengan data pada saat wawancara. Triangulasi waktu, data yang didapatkan terkait Akad Murabahah dalam KSPPS Permata Barokah Jaya, diperoleh pada saat Pihak Informan memiliki waktu luang, dan tidak sedang sibuk ataupun melakukan Survei calon anggota pembiayaan. Maka dari itu, peneliti dihimbau agar menghubungi pihak KSPPS terlebih dahulu untuk melaksanaan proses penelitian pada saat jam kerja (Moleong. Lexy J, 2007).

\section{HASIL DAN PEMBAHASAN}

\section{Sejarah Koperasi Simpan Pinjam dan Pembiayaan} Syariah (KSPPS) Permata Barokah Jaya

KSPPS Permata Barokah Jaya merupakan Lembaga Koperasi Syariah yang didirikan oleh Bapak H. Muhamad Aris Munaipada tahun 2011 dengan nama KSU Syariah Permata Barokah. Pertama kali didirikan,KSU Syariah Permata Barokah bekerjasama dengan KoperasiIntan Permata, sebagai perantara untuk mempelajari bagaimana seluk belukdan sistem dari Koperasi Syariah, hal tersebut dilakukan karena KSPPS Permata Barokah Jaya terbilang masih baru dalam mendirikan Lembaga perkoperasian. Tujuan didirikannya Koperasi Syariah ini yaitu, untuk membantu memajukan perekonomian masyarakat yang berada di Kecamatan Pandaan.

Pada akhir tahun 2013, kerjasama yang dilakukan oleh KSU Syariah Permata Barokah dengan KoperasiIntan Permata telah berakhir, namun komunikasi antar Koperasi tersebut masih terjalin hingga sekarang. Pada tahun 2019, KSU Syariah Permata Barokah mengganti nama menjadi KSPPS Permata Barokah Jaya untuk meningkatkan kepercayaan masyarakat dan berjalan sesuai dengan peraturan yang berlaku di pemerintah. KSPPSPermata Barokah Jaya kini berkembang cukup pesatdengan seiring berjalannya waktu, hal tersebut tentunya dapat terjadi karena masyarakat Kecamatan Pandaan turut berkontribusi dengan mempercayakan permasalahan keuangan kepada KSPPS Permata Barokah Jaya.Permintaan pembiayaan yang semakin meningkat hingga keluar wilayah Pandaan, menjadikan KSPPS Permata Barokah Jaya membuka beberapa cabang dan Kantor Kas di beberapa wilayah berbeda.

\section{Data Organisasi:}

1. Legalitas : KSPPS Permata Barokah Jaya

2. Alamat : Ruko Pasar Lama, Jl. Pahlawan Sunaryo, Pandaaan

3. Nomor Induk Koperasi : 3514120020008

4. Tanggal Badan Hukum : 14 Oktober 2011

Nomor Induk Koperasi dan Tanggal badan hukum yang tertera merupakan bukti bahwa KSPPS Permata Barokah Jaya merupakan Badan Hukum yang legal dan Aktif. Berikut Cabang dan Kantor Kas yang terdapat di beberapa wilayah berbeda:

Tabel 1. Daftar Kantor

\begin{tabular}{|l|l|l|}
\hline No & Kantor & Alamat \\
\hline 1. & Kantor Pusat & $\begin{array}{l}\text { Ruko Pasar Lama, Jl. } \\
\text { Pahlawan Sunaryo, Pandaaan }\end{array}$ \\
\hline 2. & $\begin{array}{l}\text { Kantor Cabang } \\
\text { Purwosari }\end{array}$ & $\begin{array}{l}\text { Jl. Raya Purwosari No. A 13 } \\
\text { Purwosari-Pasuruan }\end{array}$ \\
\hline 3. & $\begin{array}{l}\text { Kantor Cabang } \\
\text { Ngoro }\end{array}$ & $\begin{array}{l}\text { Jl. Raya Gempol-Mojokerto } \\
\text { Ds. Kecapangan Kec. Ngoro }\end{array}$ \\
\hline 4. & $\begin{array}{l}\text { Kantor Kas Ka Raya Kejapanan 165 } \\
\text { Kejapanan }\end{array}$ & $\begin{array}{l}\text { Jl. Raya Kejapanan-Gempol } \\
\text { Keje }\end{array}$ \\
\hline
\end{tabular}

Sumber: Data Primer KSPPS Permata Barokah Jaya

\section{Implementasi Pembiayaan Akad Murabahah pada KSPPS Permata Barokah Jaya}

Implementasi Pembiayaan Akad Murabahah pada KSPPS Permata Barokah Jaya menggunakan pengolahan data yang didapatkan dari hasil wawancara yang telah dilakukan oleh peneliti kepada narasumber seperti, Manajer KSPPS Permata Barokah Jaya, Staf Pembiayaan KSPPS Permata Barokah Jaya dan anggota pembiayaan Akad Murabahah. Teori ilmiah yang digunakan merujuk pada Rukun dan Syarat dari Akad Murabahah. Terdapat beberapa Implementasi pembiayaan Akad Murabahah yang diterapkan pada KSPPS Permata Barokah Jaya Kelurahan Pandaan yaitu Pertama, pelaksanaan pembiayaan Akad Murabahah dilakukan dengan menyebutkan nominal harga asli barang dan nominal keuntungan yang diambil oleh pihak KSPPS. Dalam penerapannya, terdapatrukun didalam Akad Murabahah tersebut yakni, adanya penjual dan pembeli, barang yang akan diperjual-belikan, 


\section{Jurnal Ilmiah Ekonomi Islam, 7(02), 2021, 1043}

kejelasan harga, barang yang akan dijaminkan, serta adanya Ijab dan Qabul. Berdasarkan atasapa yang ada didalam rukun Akad Murabahah tersebut menyatakan bahwa penyebutan nominal harga barang asli dan keuntungan harus dilakukan secara jelas. Hal tersebut menunjukkan bahwa KSPPS Permata Barokah Jaya telah memenuhi rukun dalam Akad Murabahah, karena terdapat kejelasan harga yang diutarakan kepada pihak anggota pembiayaan.

Kedua, barang yang akan diperjual-belikan harus sudah ada sebelum perjanjian antara kedua belah pihak dilaksanakan. Penerapan Akad Murabahah pada KSPPS Permata Barokah Jaya menggunakan sistem Murabahah bil Wakalah, pihak Koperasi Syariah memberikan uang sebesar nominal yang diminta oleh anggota pembiayaan, setelah pembelian dilakukan, nota akan diminta kembali oleh pihak Koperasi, keuntungan dari pembiayaan tersebut akan ditentukan berapa nominal yang akan diambil.Menurut hukum islam, penerapan Akad Murabahah bil Wakalah sudah sesuai.

Ketiga, KSPPS Permata Barokah Jaya mewajibkan bagi anggota pembiayaan untuk memberikan jaminan sesuai dengan jumlah nominal pembiayaan yang diminta, berupa jaminan kebendaan. Hal tersebut dilakukan oleh pihak KSPPS Permata Barokah Jaya untuk meminimalisir terjadinya pembiayaan macet, yang nantinya akan memberatkan pihak Koperasi Syariah sendiri. Dalam Q.S AlBaqarah ayat 283 menjelaskan bahwa pemberian jaminan dalam suatu pembelian diperbolehkan, agar anggota pembiayaan yang bersangkutan dalam melakukan pembelian barang secara tangguh atau angsuran tidak menyimpang. Hal tersebut juga tidak terlepas dari persetujuan dan kerelaan dari anggota pembiayaan. Penerapan adanya jaminan sudah sesuai. Adapun penerapan jaminan yang diminta oleh pihak KSPPS Permata Barokah Jaya, sebagai berikut:

Tabel 2. Jaminan yang diminta sesuai besaran Nominal

\begin{tabular}{|c|c|c|c|c|}
\hline No. & $\begin{array}{l}\text { Nama Anggota } \\
\text { Pembiayaan }\end{array}$ & $\begin{array}{l}\text { Nominal yang } \\
\text { diminta }\end{array}$ & Jaminan & $\begin{array}{l}\text { Kebutuhan Anggota } \\
\text { Pembiayaan }\end{array}$ \\
\hline 1 & Ibu Ermawati & Rp. 15.000.000,- & $\begin{array}{l}\text { ATM Gaji, Buku Nikah, Kartu } \\
\text { Jamsostek. }\end{array}$ & Renovasi Rumah \\
\hline 2 & Bapak Yoyok & Tidak disebutkan & ATM Gaji, Kartu Jamsostek. & Usaha Konveksi Pakaian \\
\hline 3 & Bapak Wahyu & Rp. 4000.000,- & $\begin{array}{l}\text { ATM Gaji, Buku Tabungan, Surat } \\
\text { Nikah }\end{array}$ & Usaha Warung Kopi \\
\hline 4 & Bapak M. Imron & Rp. 15.000 .000 & ATM Gaji, Kartu BPJS & Pembangunan Rumah. \\
\hline 5 & $\begin{array}{l}\text { Bapak M. Fathur } \\
\text { Rozak }\end{array}$ & Tidak disebutkan & ATM Gaji, BPKB Motor. & $\begin{array}{lll}\text { Biaya } & \text { kebutuhan } & \text { anak } \\
\text { sekolah. } & & \end{array}$ \\
\hline 6 & Bapak M Yamin & Rp. 6000.000,- & $\begin{array}{l}\text { ATM Gaji, Kartu Jamsostek, } \\
\text { Ijazah }\end{array}$ & Renovasi Rumah. \\
\hline 7 & Ibu Hadi & Rp. 4000.000,- & ATM Gaji, Buku Tabungan. & $\begin{array}{ll}\text { Biaya kebutuhan } & \text { Anak } \\
\text { Sekolah } & \end{array}$ \\
\hline 8 & Bapak Mukhlas & Rp. 30.000.000,- & $\begin{array}{l}\text { ATM Gaji, Buku Tabungan, } \\
\text { Ijazah, Sertifikat rumah }\end{array}$ & $\begin{array}{l}\text { Biaya kebutuhan Anak } \\
\text { Sekolah, dan lain-lain. }\end{array}$ \\
\hline 9 & $\begin{array}{l}\text { Bapak } \\
\text { Sudarmanto }\end{array}$ & Rp. 5000.000,- & $\begin{array}{l}\text { ATM Gaji, Buku Tabungan, } \\
\text { Ijazah. }\end{array}$ & Renovasi Rumah. \\
\hline 10 & Bapak Didik & Rp. 20.000.000,- & ATM Gaji, BPKB Motor. & Renovasi Rumah. \\
\hline 11 & Bapak Akhyat & Rp. 3000.000,- & ATM Gaji, Kartu Jamsostek. & Renovasi Rumah. \\
\hline 12 & Bapak Istono & Rp. 10.000.000,- & ATM Gaji, Kartu Jamsostek. & Renovasi Rumah. \\
\hline 13 & Bapak Andi & Rp. 2.000.000,-- & ATM Gaji, BPKB Motor. & Renovasi Rumah. \\
\hline 14 & Bapak Dodik & Rp. 10.000.000,- & $\begin{array}{l}\text { ATM Gaji, Buku Tabungan, Surat } \\
\text { keterangan Pegawai Tetap. }\end{array}$ & Renovasi Rumah. \\
\hline 15 & Bapak Sugeng & Rp. 25.000.000,- & ATM Gaji. & $\begin{array}{l}\text { Pembangunan Rumah, Biaya } \\
\text { kebutuhan sekolah anak. }\end{array}$ \\
\hline 16 & Bapak Abdillah & Rp. 20.000.000,- & ATM Gaji, NPWP, BPKB Motor. & $\begin{array}{l}\text { Kebutuhan Keluarga, Usaha } \\
\text { sewa Sound System. }\end{array}$ \\
\hline
\end{tabular}


Jurnal Ilmiah Ekonomi Islam, 7(02), 2021, 1044

\begin{tabular}{|c|l|l|l|l||}
\hline No. & $\begin{array}{l}\text { Nama Anggota } \\
\text { Pembiayaan }\end{array}$ & $\begin{array}{c}\text { Nominal yang } \\
\text { diminta }\end{array}$ & \multicolumn{1}{|c||}{ Jaminan } & \multicolumn{1}{|c||}{$\begin{array}{c}\text { Kebutuhan Anggota } \\
\text { Pembiayaan }\end{array}$} \\
\hline 17 & Bapak Rifa'i & Rp. 3000.000,- & ATM Gaji. & $\begin{array}{l}\text { Biaya kebutuhan anak } \\
\text { sekolah. }\end{array}$ \\
\hline 18 & Bapak Mistar & Rp. 4000.000,- & ATM Gaji, Kartu Jamsostek & Pembangun Rumah. \\
\hline 19 & Ibu Kholifah & Rp. 3000.000,- & ATM Gaji, Surat Nikah & Renovasi Rumah \\
\hline 20 & $\begin{array}{l}\text { Bapak } \\
\text { Ruswandana }\end{array}$ & Rp. 7.000.000,- & ATM Gaji, Dana Pensiun & Pembangunan Rumah \\
\hline
\end{tabular}

Sumber: Data Primer yang diolah

Dari Tabel diatas, dapat diketahui bahwa terdapat 20 orang Informan dengan permintaan pembiayaan Akad Murabahah yang berbeda. 3 orang diantaranya mempergunakan pembiayaan tersebut untuk usaha yang tengah dirintis.

Keempat, pembiayaan Akad murabahah dilakukan atas persetujuan antara kedua belah pihak, dengan menjelaskan secara rinci bagaimana sistem dari Akad Murabahah, dan pembayaran secara tangguh atau angsuran setiap bulan melalui sistem potong Gaji secara langsung pada saat pencairan gaji anggota pembiayaan Akad Murabahah keluar. Penerapan Akad Murabahah dengan sistem potong Gaji anggota pembiayaan secara langsung sudah sesuai, dikarenakan adanya pelaksanaan Ijab dan Qabul. Hal tersebut menunjukkan suatu kerelaan oleh pihak anggota pembiayaan.

Dari 20 orang anggota pembiayaan, terdapat 4 orang anggota yang masih belum memahami Akad Murabahah dan bagaimana pelaksanaannya. Hal tersebut dikarenakan pada saat pihak KSPPS Permata Barokah Jaya menjelaskan dan memberikan surat perjanjian berisikan penjelasan terkait pembiayaan, anggota tidak mendengarkan dan hanya menandatangani tanpa membaca surat tersebut.

Prosedur pembiayaan Akad Murabahah dapat dilakukan oleh calon anggota pembiayaan Akad Murabahah KSPPS Permata Barokah Jaya, sebagai berikut:

a. Calon Anggota mendatangi KSPPS Permata Barokah Jaya untuk mengajukan Pembiayaan Akad Murabahah.

b. Calon Anggota mengisi formulir yang telah disediakan oleh KSPPS Permata Barokah Jaya.

c. Persyaratan umum dibawa pada saat pengajuan pembiayaan Akad Murabahah dilakukan, seperti Foto Copy KTP, Foto Copy Kartu Keluarga.

d. Membawa benda yang akan dijadikan Jaminan, seperti ATM Gaji, BPKB Motor, Sertifikat
Tanah/Bangunan, Kartu Jamsostek, Buku Nikah, dan lain-lain.

e. Setelah menyerahkan semua Syarat-syarat pengajuan pembiayaan Akad Murabahah, calon anggota disuruh untuk menunggu selama 3 hari hingga 2 minggu.

f. Survey calon anggota pembiayaan.

g. Jika calon anggota pembiayaan tersebut dapat dinyatakan layak, maka pencairan akan dilakukan.

Dampak Implementasi Pembiayaan Akad Murabahah di KSPPS Permata Barokah Jaya dalam Upaya Peningkatan UMKM Kelurahan Pandaan

KSPPS Permata Barokah Jaya berada di tengahtengah banyaknya Usaha Mikro, Kecil dan Menengah (UMKM). Hal tersebut tentunya akan dapat lebih memudahkan masyarakat Kelurahan Pandaan dalam mengajukan pembiayaan Akad Murabahah, untuk kebutuhan mereka. Berdasarkan data pada Tahun 2019, Jumlah UMKM yang tersebar di Kelurahan Pandaan berjumlah kurang lebih 211 unit dengan berbagai macam jenis bidang usaha yang dijalankan. Berikut merupakan data UMKM Kelurahan Pandaan. Gambar 1.

Jenis Usaha yang dijalankan oleh warga Kelurahan Pandaan

\section{Jenis Usaha Kelurahan Pandaan}

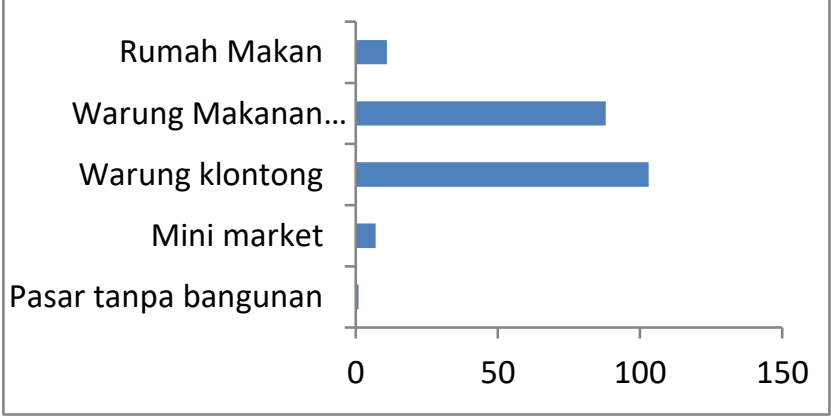

Sumber: Badan Pusat Statistik Kabupaten Pasuruan 2019 
Pada diagram batang diatas, dapat dilihat bahwa cukup banyak Usaha Mikro, Kecil dan Menengah (UMKM) dengan 5 jenis bentuk usaha, yang paling banyak berjumlah 103 unit.yakni Warung Klontong dan Warung Makanan dan Minuman dengan jumlah 88 unit.

Pembiayaan menggunakan Akad Murabahah yang diterapkan oleh KSPPS Permata Barokah Jaya ini, bertujuan untuk mencukupi pembelian kebutuhan dari anggota yang bermacam-macam. Permintaan pembiayaan yang paling banyak diajukan oleh anggota dipergunakan untuk pembelian bahan bangunan renovasi Rumah, Biaya kebutuhan Sekolah, Biaya kebutuhan sehari-hari, dan modal usaha, yang diajukan oleh Karyawan sebuah Pabrik dan pelaku UMKM.

Survey yang dilakukan oleh pihak KSPPS Permata Barokah Jaya menggunakan prinsip 5C Pertama, Character Behavior yang dilihat dari interaksi antara calon anggota pembiayaan dengan keluarga maupun tetangga disekitar tempat tinggalnya. Kedua, Condition of Economy yang dapat dlihat dari pekerjaan dan usaha yang dijalankan oleh calon anggota, apakah dapat mencukupi kebutuhan hidupnya atau tidak. Ketiga, Capacity kemampuan dalam memanajemen, menghandle pekerjaan yang ditekuni dengan baik. Keempat Capital, dilihat dari bagaimana calon anggota dapat memanfaatkan keuangannya dengan baik. Kelima, Collateral kemampuan pihak KSPPS Permata Barokah Jaya dalam menganalisis pekerjaan yang tengah ditekuni oleh calon anggota. Keenam Constrain, ketepatan dalam pemberian pembiayaan Akad Murabahah dapat berkaitan dengan bagaimana kondisi pekerjaan calon anggota pembiayaan tersebut.

Dalam hal ini, point Constrain menjadi acuan utama KSPPS Permata Barokah Jaya dalam memberikan pencairan pembiayaan terhadap Karyawan tetap pabrik, dikarenakan kondisi baik dengan gaji yang sama setiap bulannya, memudahkan KSPPS Permata Barokah Jaya dalam memotong nominal pada ATM Gaji anggota guna melunasi tanggungan angsuran pada setiap bulannya. Oleh karena itu, KSPPS Permata Barokah Jaya memutuskan untuk memfokuskan pemberian pembiayaan kepada Karyawan Pabrik.

Berdasarkan hasil wawancara peneliti dengan Manajer KSPPS Permata Barokah Jaya dan Staf pembiayaan KSPPS Permata Barokah Jaya, dapat disimpulkan bahwa pemberian pembiayaan didominasi oleh anggota yang berprofesi sebagai Karyawan Pabrik. Berikut adalah perbandingan pemberian pembiayaan terhadap karyawan pabrik dan pelaku UMKM.

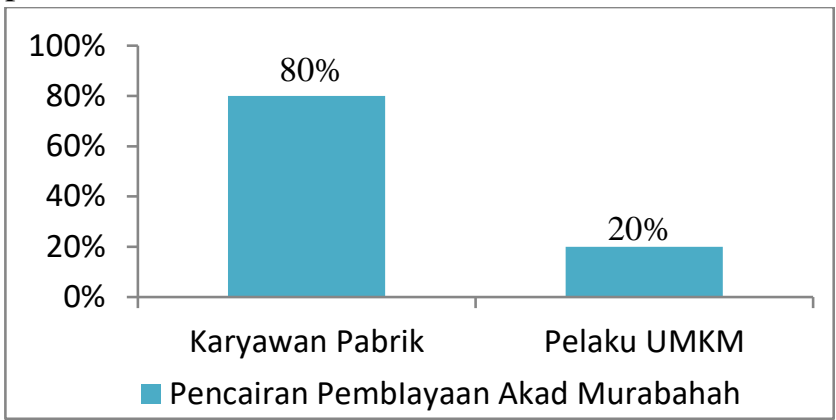

Gambar 2. Pemberian Pembiayaan Akad Murabahah

Sumber: Data Primer yang diolah

Pada diagram batang diatas menunjukkan adanya perbedaan pemberian pembiayaan yang memang lebih difokuskan kepada Karyawan Pabrik. Hal tersebut dilakukan oleh KSPPS Permata Barokah Jaya dikarenakan Karyawan Pabrik memiliki jaminan yang cukup untuk menjadi bukti bahwa anggota tersebut tidak akan lepas tanggungan terkait angsuran yang telah disepakati pada awal Ijab Qabul dilaksanakan.

Hal tersebut dapat diperkuat dengan adanya observasi yang dilakukan oleh peneliti dan wawancara dengan anggota pembiayaan Akad Murabahah. Hasil observasi menunjukkan bahwa yang paling banyak mengajukan pembiayaan Akad Murabahah bekerja sebagai Karyawan Pabrik. Anggota pembiayaan yang berprofesi menjadi karyawan pabrik, mengaku sangat terbantu dengan adanya pembiayaan Akad Murabahah yang diberikan oleh KSPPS Permata Barokah Jaya, begitupun juga sedikit dari banyaknya pelaku UMKM yang diberikan pembiayaan, mengaku juga sangat terbantu dalam mengembangkan usahanya.

KSPPS Permata Barokah Jaya, tidak pernah memberikan batasan kepada seluruh masyarakat Kelurahan Pandaan dalm mengajukan Pembiayaan. Namun, calon anggota harus memberikan jaminan yang dapat meyakinkan pihak KSPPS Permata Barokah Jaya, bahwa calon anggota tersebut benar bertanggung-jawab atas pembiayaannya.

\section{KESIMPULAN}

Berdasarkan hasil dari wawancara dan observasi yang dilakukan oleh peneliti, maka dapat disimpulkan bahwa Implementasi Pembiayaan Akad Murabahah pada KSPPS Permata Barokah Jaya, telah sesuai 
dengan prinsip Syariah. Namun, terdapat empat orang anggota pembiayaan yang belum paham terkait apa itu dan bagaimana penerapan Akad Murabahah. Hal tersebut dapat terjadi dikarenakan anggota pembiayaan tidak mendengarkan pada saat perjanjian Akad Murabahah djelaskan oleh pihak KSPPS Permata Barokah Jaya dan tidak membaca dengan seksama isi dari surat perjanjian yang diberikan sebelum ditanda-tangani. Pembiayaan Akad Murabahah yang dterapkan oleh KSPPS Permata Barokah Jaya, didominasi oleh anggota yang berprofesi sebagai Karyawan Pabrik. Hal tersebut dikarenakan anggota pembiayaan Karyawan Pabrik memiliki Jaminan ATM Gaji, yang dapat dipotong setiap bulan pada saat gajian. Namun, KSPPS Permata Barokah Jaya tidak pernah memberikan batasan kepada seluruh masyarakat Kelurahan Pandaan dalam mengajukan pembiayaan Akad Murabahah, asalkan calon aggota tersebut memiliki jaminan yang dapat meyakinkan KSPPS Permata Barokah Jaya, jika calon anggota bersedia bertanggung-jawab atas pembiayaan yang akan diajukan.

\section{DAFTAR PUSTAKA}

Anggraeni, L., Puspitasari, H., El Ayubbi, S., \& Wiliasih, R. (2013). Akses UMKM Terhadap Pembiayaan Mikro Syariah dan Dampaknya Terhadap Perkembangan Usaha: Kasus BMT Tadbiirul Ummah, Kabupaten Bogor The Access of MSME towards Islamic Microfinancing and Its Impact on Business Development: A Case of BMT Tadbiirul Ummah, Bo. Pembiayaan Mikro Syariah Jurnal Al-Muzara'ah, I(1), 56.

Asfino, A. A., \& Prabowo, P. S. (2019). Kata kunci:Peran BMT Bina Ummat Sejahtera Cabang Montong Melalui Pembiayaan Murabahah dalam Upaya Penguatan Ekonomi UMKM. Jurnal Ekonomi Islam, 2(1), 1-9.

Badan Pusat Statistik Indonesia. (2019). Badan Pusat Statistik Indonesia. https://www.bps.go.id

Bonita, S. D., \& Anwar, A. Z. (2018). Implementasi Syariah Compliance pada Akad Murabahah dan Ijarah (Studi Kasus Pada KSPPS BMT Fastabiq Jepara). JESI (Jurnal Ekonomi Syariah Indonesia), $7(2), \quad 88$. https://doi.org/10.21927/jesi.2017.7(2).90-99
Budiantoro, R. A., Larasati, P. P., \& Herianingrum, S. (2018). Strategi Pengembangan Program Pemberdayaan Usaha Mikro Dan Kecil Melalui Pembiayaan Usaha Syariah Di Kota Mojokerto. IQTISHADIA: Jurnal Ekonomi \& Perbankan Syariah, 5(2), 284. https://doi.org/10.19105/iqtishadia.v5i2.1937

Hakim, L., \& Anwar, A. (2017). PEMBIAYAAN MURABAHAH PADA PERBANKAN SYARIAH DALAM PERSPEKTIF HUKUM DI INDONESIA Lukmanul. AL-URBAN: Jurnal Ekonomi Syariah Dan Filantropi Islam, 1(2), 212-223. https://doi.org/10.22236/alurban

Haryanto, S. (2011). Potensi Dan Peran Lembaga Keuangan Mikro (Lkm) Dalam Upaya Pengembangan Usaha Kecil Dan Mikro. Jurnal Ekonomi Modernisasi, 7(3), 229-238.

Hasiara, L. O. (2012). Metode Penelitian Multi Paradigma Satu Pembangun reruntuhan Metode Penelitian yang berserakan. Darkah Media.

IKNB Otoritas Jasa Keuangan. (2017). Otoritas Jasa Keuangan. https:www.ojk.go.id

Ilyas, A., \& Sartika, D. (2018). Analisis Kesehatan Koperasi Syariah di Kota Padang. Jurnal Ekonomi Dan Bisnis Dharma Andalas, 20(2).

Imama, \& Shoa, L. (2014). Konsep dan Implementasi Murabahah pada Produk Pembiayaan Bank Syariah. IQTISHADIA: Jurnal Ekonomi \& Perbankan Syariah, 11.

Kementerian Koperasi dan Usaha Mikro Kecil dan Menengah. (2018). Kementerian Koperasi Dan Usaha Mikro Kecil Dan Menengah. https://www.depkop.go.id

Kementerian Koperasi dan Usaha Mikro Kecil dan Menengah. (2019). Kementerian Koperasi Dan Usaha Mikro Kecil Dan Menengah. https://www.depkop/go.id

Kusuma, I. L., Dewi, M. W., \& Tho'in, M. (2021). Analysis of the Effect of Human Resources Competency, Utilization of Technological Information, and Internal Control Systems on the Value of Financial Reporting Information. Annals of the Romanian Society for Cell Biology, 14628-14638.

Moleong. Lexy J. (2007). Metodologi Penelitian Kualitatif (T. Sujarman (Ed.); Cetakan 4). Remaja Rosda Karya. 
Novita, L., Nawawi, M. K., \& Hakiem, H. (2014). PENGARUH PEMBIAYAAN MURABAHAH TERHADAP PERKEMBANGAN UMKM DI KECAMATAN LEUWILIANG (STUDI KASUS BPRS AMANAH UMMAH) Linda Novita. Al-Infaq: Jurnal Ekonomi Islam, 5(2), 273-310.

Nuryanto, R., Tho'in, M., \& Wardani, H. K. (2014). Rasio Likuiditas, Rasio Solvabilitas, Rasio Rentabilitas Koperasi Jasa Keuangan Syariah Di Jawa Tengah. Jurnal Akuntansi dan Pajak, 15(01).

Oktafia, R. (2017). Percepatan Pertumbuhan Usaha Mikro, Kecil Dan Menengah (Umkm) Melalui Perkuatan Lembaga Keuangan Mikro Syariah (Lkms) Di Jawa Timur. Jurnal Ekonomi Islam, 3(1), h. 85-92.

Raco, J, R. (2010). Metode Penelitian Kualitatif Jenis, Karakteristik dan Keunggulannya (L. Arita (Ed.)). PT. Gramedia Widiasarana Indonesia.
Romdhoni, A. H., Tho'in, M., \& Wahyudi, A. (2012). Sistem Ekonomi Perbankan Berlandaskan Bunga (Analisis Perdebatan Bunga Bank Termasuk Riba Atau Tidak). Jurnal Akuntansi dan Pajak, 13(01).

Sari, P., \& Rusdiono. (2020). Analisis Sistem Pembiayaan Murabahah Pada KSPPS BMT Amanah Ray. Jurnal Studi Manajemen, 2(1), 4750 .

Sugiyono. (2017). Metode penelitian Kuantitatif, Kualitatif, $R \& D$. Alfabeta.

Tho'in, M., \& Prastiwi, I. E. (2019). An Analysis the Rupiah Exchange Rates Effect Against the American Dollar and Inflation Against the Growth of Islamic Banking Mudharabah Deposits in Indonesia. International Journal of Islamic Business and Economics (IJIBEC), 3(1), 82-91. 